\title{
Intrathecal antitetanus serum (horse) with steroid in the treatment of neonatal tetanus
}

\author{
ARUN KUMAR SINGH, ASHWANI BANSAL, S P GOEL, AND V K AGARWAL \\ Department of Paediatrics, MLN Medical College, Allahabad, India
}

SUMMARY 107 patients with neonatal tetanus were studied and the value of intrathecal antitetanus serum with steroid was noted. The mortality rate in a control group $(68 \%)$ was significantly higher than that of the test group (37\%). Furthermore, a delay in antitetanus serum administration was found to have a strong positive linear correlation with the mortality rate. In fact, the mortality rate for neonates who were given antitetanus serum 24 hours after the onset of convulsions was found to be as high as for the control group. This suggests that intrathecal antitetanus serum is ineffective unless it is administered within 24 hours of the onset of convulsions. There was no significant difference in mortality rate whether a dose of 100 units or one of 50 units antitetanus serum was given intrathecally. The mean duration in hospital for survivals of the test group ( 7.4 days) was significantly shorter than that for survivals of the control group (10.4 days). No complication of intrathecal antitetanus serum was observed during the study.

Neonatal tetanus is associated with a high mortality and accounts for about $55 \%$ of neonatal deaths in rural India. ${ }^{1}$ In one survey ${ }^{2}$ it was reported to be the second most common killer of neonates; the first was prematurity. In many places the mortality even today ranges from 70 to $90 \%$ (Table 1). We have tried to reduce this mortality rate by using a method of treatment which is both economical and feasible, even for centres lacking elaborate facilities.

Experimental studies with intrathecal antitetanus serum (ATS) in animals have shown encouraging results. ${ }^{3-5} 17$ Some workers ${ }^{6-8}$ have tried ATS in adults with tetanus, but little work has been done to assess its value in the treatment of tetanus neonatorum. ${ }^{9}$

Table 1 Mortality rates at various centres

\begin{tabular}{|c|c|c|c|}
\hline Author & Place & $\begin{array}{l}\text { No of } \\
\text { cases }\end{array}$ & $\begin{array}{l}\text { Mortality } \\
\text { rate } \\
(\%)\end{array}$ \\
\hline $\begin{array}{l}\text { Pathak and Shah } 13 \\
\text { Vaishnava et al.14 } \\
\text { Vakil et al. } .^{15} \\
\text { Mehrotra et al.12 } \\
\text { Loh Siew Gek }{ }^{18} \\
\text { Spivey et al. }{ }^{16} \\
\text { Lorenz }{ }^{19}\end{array}$ & $\begin{array}{l}\text { Medical College, Baroda } \\
\text { Irwin Hospital, Delhi } \\
\text { JJ Group of Hospitals, } \\
\text { Bombay } \\
\text { SN Children's Hospital*, } \\
\text { Allahabad } \\
\text { Malaya } \\
\text { New Orleans, USA } \\
\text { Dresden, Germany }\end{array}$ & $\begin{array}{l}123 \\
465 \\
102\end{array}$ & $\begin{array}{l}88 \\
77 \\
\\
87 \\
\\
79 \\
91 \\
77 \\
60\end{array}$ \\
\hline
\end{tabular}

*Part of MLN Medical College.

\section{Materials and method}

The study was conducted in the isolation ward of SN Children's Hospital, Allahabad, during August and September 1978. The diagnosis was made clinically, and was independently confirmed by two senior consultants. All cases of tetanus neonatorum coming to the hospital were admitted. Admissions were labelled alternately as test (T) or control (C) by the sister in charge of the ward, and each patient was allotted a number. Patients in the test group were divided further, and given 100 or 50 units ATS intrathecally, thus forming subgroup A or B. Two patients, in whom lumbar punctures failed (T9 and T26), were excluded from the study. Similarly 6 other patients (T1, T39, C29, C36, C39, and C3) left hospital against medical advice and likewise were omitted from the study. For administrative reasons it was not possible to have a double-blind trial, so a single-blind trial was carried out.

107 babies were admitted with tetanus during the period of the study, so (excluding the 8) 99 cases were thus available (49 in the test group, and 50 in the control group). 26 babies received 100 units ATS intrathecally (subgroup A), and 23 babies received 50 units intrathecally (subgroup $B$ ).

Lumbar puncture was done with the baby well 
sedated. 100 units (or 50 units) ATS were diluted in $1 \mathrm{ml}$ (or $0.5 \mathrm{ml}$ ) distilled water and this dose was injected intrathecally, together with $2 \mathrm{mg}$ dexamethasone. Dexamethasone was added to lessen the risk of damage to the central nervous system by a foreign serum.

Sedation. This was given in three schedules. Schedule 1 was given to patients with grade I, II, or III severity, and schedule 2 to patients with grade IV or V severity. Some patients with grade V severity, who were not able to be controlled with schedule 2 alone were given schedule 3 treatment.

\section{Grading}

Schedule 1 comprised chlorpromazine $5 \mathrm{mg}$, promethazine $5 \mathrm{mg}$, and sodium phenobarbitone $7.5 \mathrm{mg}$ given through an orogastric feeding tube and repeated 8-hourly or less often. In schedule 2 , the same drugs were used but sometimes the amounts were doubled, and they were repeated either 6hourly or 4-hourly. In schedule 3 , the patient was kept on intravenous diazepam $(0.2$ to $0.5 \mathrm{mg} / \mathrm{kg}$ per day), promethazine ( 5 to $7 \mathrm{mg} / \mathrm{kg}$ per day) and sodium phenobarbitone (6 to $10 \mathrm{mg} / \mathrm{kg}$ per day) were given in an infusion, the rate of infusion being adjusted according to the reflex spasms and general condition of the patient. Paraldehyde $(0.15 \mathrm{ml} / \mathrm{kg})$ rectally was given if necessary to control convulsions.

Antitetanus serum (horse). 10000 units of ATS were given intramuscularly to all patients in both groups.

Care of umbilical stump. The umbilical cord of each patient was cleaned daily with spirit and $1 \%$

Table 2 Mortality rates in the two groups

\begin{tabular}{llll}
\hline Group & No of cases & Deaths & $\begin{array}{l}\text { Mortality } \\
\text { rate } \\
(\%)\end{array}$ \\
\hline Test & 49 & 18 & 37 \\
Control & 50 & 34 & 68 \\
Total & 99 & 52 & 53 \\
\hline
\end{tabular}

$x^{2}=9.64, \mathrm{P}<0.005$. gentian violet applied, as this was the presumed portal of entry for the infection.

Antibiotics. 100000 units of penicillin were given intramuscularly twice a day to all patients, together with $100 \mathrm{mg}$ streptomycin intramuscularly daily. Any subsequent infection was treated by the appropriate antibiotic.

Other drugs. Symptomatic treatment for various complications and symptoms-such as fever, constipation, diarrhoea, abdominal distension, chest infection-was given as and when required.

Nutrition. Feeding was 4-hourly via an orogastric feeding tube, inserted by trained staff, and removed after giving the feeds and medicines. Any patient who had continuous spasms was given parenteral nutrition in case he inhaled vomit.

General management. Patients were kept in a separate, quiet ward and were handled as little as possible.

\section{Results}

The overall mortality rate for the 99 babies was $53 \%(68 \%$ in the control group and $37 \%$ in the test group) (Table 2).

Age distribution. The earliest age at which tetanus was observed was 3 days and the oldest patient was 13 days, the age being recorded at the onset of disease. As the infection occurs at birth, the age of the patient coincided well with the incubation period of the disease (Table 3).

The mean incubation period for test group patients was 6.5 days, that for the control group 6.9 days; the difference is not significant.

Sex ratio. There were 10 girls ( 3 in the test group, 7 in the control group), constituting $10 \%$ of the total number. Overall female mortality rate was $40 \%$ compared with $54 \%$ for males; the difference is not significant. The fact that there was a smaller number of girls in the study is perhaps because fewer girls are brought to hospital, or it is possible

Table 3 Mortality rates in relation to incubation period

\begin{tabular}{|c|c|c|c|c|c|c|c|}
\hline \multirow{2}{*}{$\begin{array}{l}\text { Incubation period } \\
\text { (days) }\end{array}$} & \multicolumn{3}{|c|}{ Test group } & \multicolumn{3}{|c|}{ Control group } & \multirow[t]{2}{*}{ Significance* of difference } \\
\hline & $\begin{array}{l}\text { No of } \\
\text { cases }\end{array}$ & Deaths & $\begin{array}{l}\text { Mortality } \\
\text { rate }(\%)\end{array}$ & $\begin{array}{l}\text { No of } \\
\text { cases }\end{array}$ & Deaths & $\begin{array}{l}\text { Mortality } \\
\text { rate }(\%)\end{array}$ & \\
\hline $\begin{array}{l}3 \text { to }<5 \\
5 \text { to }<7 \\
7 \text { to }<9 \\
9 \text { to }<11 \\
11 \text { and longer } \\
\text { Total }\end{array}$ & $\begin{array}{r}4 \\
23 \\
19 \\
3 \\
0 \\
49\end{array}$ & $\begin{array}{r}2 \\
11 \\
4 \\
1 \\
0 \\
18\end{array}$ & $\begin{array}{r}50 \\
48 \\
21 \\
33 \\
0 \\
37\end{array}$ & $\begin{array}{r}4 \\
24 \\
16 \\
4 \\
2 \\
50\end{array}$ & $\begin{array}{r}4 \\
20 \\
9 \\
1 \\
0 \\
34\end{array}$ & $\begin{array}{r}100 \\
88 \\
56 \\
25 \\
0 \\
68\end{array}$ & $\begin{array}{l}P<0.50 \\
P<0.02 \\
P<0.05 \\
- \\
\bar{P}<0.005\end{array}$ \\
\hline
\end{tabular}

* $\chi^{2}$ test, after continuity correction. 
that girls are less affected by the disease. Once the disease has established itself the course is similar, regardless of gender.

Period of onset. The time from the onset of first symptom to the first reflex spasm occurring in the neonate has been taken as the period of onset. The shorter the period of onset, the greater is the mortality (Table 4). The mean period of onset for babies in the test group was $14 \cdot 1$ hours and that for babies in the control group 15.4 hours; the difference is not significant.

Socioeconomic status. 81 cases in the study came from the rural areas, where the incidence of neonatal tetanus is higher. However, mortality figures for the rural and urban areas were 54 and $47 \%$ respectively; the difference is not significant.

Grading. Patients were graded for the severity using the classification of Patel and Joag. ${ }^{10}$ The following features were noted: (1) Presence of lockjaw. (2) Presence of spasms. (3) Incubation period of 7 days or less. (4) Period of onset of convulsions of 48 hours or less. (5) Axillary or rectal temperature of at least $37 \cdot 2^{\circ} \mathrm{C}$ at admission or within 24 hours of admission.

Patients with all five features were classified as having grade $\mathrm{V}$ severity, those with four were grade IV, those with only three were grade III, and so on. The majority of cases were grade IV or V. There were only 2 patients with grade II; both were in the control group and both survived. No case of grade I tetanus was brought to the hospital. The degree of severity was similar in both groups.
Severity of the disease was clearly related to mortality (Table 5).

11 patients with grade II or III severity were given schedule I sedation. 66 patients with grade IV or $\mathrm{V}$ severity were given schedule 2 , while 22 patients (12 in the test group and 10 in the control group) were given parenteral sedation (schedule 3). 17 patients given schedule 3 died (9 in the test group and 8 in the control group).

Delay in giving intrathecal ATS. A linear relation exists between the delay in giving intrathecal ATS and mortality (Table 6). There is also a steep rise in mortality if ATS is given later than 24 hours after onset, although the number of cases in this group was small. This suggests that delay in giving ATS intrathecally is associated with higher rates of mortality, and that ATS is not of much benefit if

Table 6 Mortality rates in relation to delay in giving intrathecal antitetanus serum

\begin{tabular}{llll}
\hline Delay & No of cases & Deaths & $\begin{array}{l}\text { Mortality } \\
\text { rate } \\
(\%)\end{array}$ \\
\hline 0 to $<8$ hours & 17 & 4 & 24 \\
8 to $<16$ hours & 13 & 4 & 31 \\
16 to $<24$ hours & 15 & 7 & 47 \\
24 hours and longer & 4 & 3 & 75 \\
\hline
\end{tabular}

Correlation coefficient ' $r$ ' $=+0.96$.

Calculation of ' $r$ ': the correlation between number of hours delayed in giving ATS and mortality rate is calculated by arbitrarily grouping the number of hours of delay with the class interval of 8 hours, and observing the mortality rate in each class interval. ' $r$ ' is calculated assuming that the midpoint of each interval can reasonably be substituted for calculations-for example, mortality rate $24 \%$ can be presumed to be concentrated at 4 hours' delay in giving ATS, and so on.

Table 4 Mortality rates in relation to period of onset

\begin{tabular}{|c|c|c|c|c|c|c|c|}
\hline \multirow{2}{*}{$\begin{array}{l}\text { Period of onset } \\
\text { (hours) }\end{array}$} & \multicolumn{3}{|c|}{ Test group } & \multicolumn{3}{|c|}{ Control group } & \multirow[t]{2}{*}{ Significance* of difference } \\
\hline & $\begin{array}{l}\text { No of } \\
\text { cases }\end{array}$ & Deaths & $\begin{array}{l}\text { Mortality } \\
\text { rate }(\%)\end{array}$ & $\begin{array}{l}\text { No of } \\
\text { cases }\end{array}$ & Deaths & $\begin{array}{l}\text { Mortality } \\
\text { rate }(\%)\end{array}$ & \\
\hline $\begin{array}{l}0 \text { to }<12 \\
12 \text { to }<24 \\
24 \text { to }<36 \\
36 \text { and longer }\end{array}$ & $\begin{array}{r}26 \\
15 \\
6 \\
2\end{array}$ & $\begin{array}{r}13 \\
4 \\
1 \\
0\end{array}$ & $\begin{array}{r}50 \\
27 \\
20 \\
0\end{array}$ & $\begin{array}{r}24 \\
16 \\
7 \\
3\end{array}$ & $\begin{array}{r}18 \\
11 \\
3 \\
2\end{array}$ & $\begin{array}{l}75 \\
69 \\
43 \\
67\end{array}$ & $\begin{array}{l}\mathbf{P}<0.1 \\
\mathbf{P}<0.05 \\
\mathbf{P}<0.5 \\
\mathbf{P}<0.1\end{array}$ \\
\hline
\end{tabular}

$\chi^{2}$ test after continuity correction.

Table 5 Mortality rates in relation to severity

\begin{tabular}{|c|c|c|c|c|c|c|c|}
\hline \multirow[t]{2}{*}{ Severity } & \multicolumn{3}{|c|}{ Test group } & \multicolumn{3}{|c|}{ Control group } & \multirow[t]{2}{*}{ Significance* of difference } \\
\hline & $\begin{array}{l}\text { No of } \\
\text { cases }\end{array}$ & Deaths & $\begin{array}{l}\text { Mortality } \\
\text { rate }(\%)\end{array}$ & $\begin{array}{l}\text { No of } \\
\text { cases }\end{array}$ & Deaths & $\begin{array}{l}\text { Mortality } \\
\text { rate }(\%)\end{array}$ & \\
\hline $\begin{array}{l}\text { Grade II } \\
\text { Grade III } \\
\text { Grade IV } \\
\text { Grade V }\end{array}$ & $\begin{array}{r}0 \\
4 \\
11 \\
34\end{array}$ & $\begin{array}{r}0 \\
0 \\
2 \\
18\end{array}$ & $\begin{array}{r}0 \\
0 \\
18 \\
53\end{array}$ & $\begin{array}{r}2 \\
5 \\
10 \\
33\end{array}$ & $\begin{array}{r}0 \\
3 \\
7 \\
24\end{array}$ & $\begin{array}{r}0 \\
60 \\
70 \\
73\end{array}$ & $\begin{array}{l}-\vec{P}<0.10 \\
P<0.05 \\
P<0.10\end{array}$ \\
\hline
\end{tabular}

* $\chi^{2}$ test after continuity correction. 
given later than 24 hours after the onset of the first spasm (Table 6).

Dose of intrathecal ATS. ATS intrathecally was given with $2 \mathrm{mg}$ of dexamethasone in two subgroups. 100 units of ATS were given to 26 patients (subgroup A) and 50 units ATS to 23 patients (subgroup B). 9 patients died in each subgroup. Case fatality rates were 35 and $39 \%$ respectively for subgroups $\mathbf{A}$ and $\mathbf{B}$. These data show there was no appreciable difference $\left(\chi^{2}=0 \cdot 105 ; \mathrm{df}=1\right)$ in fatality rates whether a dose of 100 units or 50 units ATS was given.

Hospital stay. Intrathecal ATS helped to reduce the duration spent in hospital (Table 7). Generally the hospital stay for patients in the test group was $7 \cdot 4$ days while that for patients in the control group was $10 \cdot 4$ days; the difference is significant $(P<0.05)$.

Time of death. Table 8 shows the times of death from the onset of first symptom. There was no significant difference in the mean time of death between the test and control groups. The precise cause of death could not be ascertained in most cases as necropsies were not performed.

Complications of intrathecal ATS. No immediate complication was observed and patients were

Table 7 Duration in hospital of the patients who survived in the two groups

\begin{tabular}{|c|c|c|c|c|}
\hline \multirow{2}{*}{$\begin{array}{l}\text { Duration in } \\
\text { hospital } \\
\text { (days) }\end{array}$} & \multicolumn{2}{|c|}{ Test group $(n=31)$} & \multicolumn{2}{|c|}{ Control group $(n=16)$} \\
\hline & $\begin{array}{l}\text { No of } \\
\text { cases }\end{array}$ & $\%$ & $\begin{array}{l}\text { No of } \\
\text { cases }\end{array}$ & $\%$ \\
\hline $\begin{array}{l}3 \text { to }<5 \\
5 \text { to }<7 \\
7 \text { to }<9 \\
9 \text { to }<11 \\
11 \text { and longer }\end{array}$ & $\begin{array}{l}6 \\
8 \\
6 \\
6 \\
5\end{array}$ & $\begin{array}{l}19 \\
26 \\
19 \\
19 \\
16\end{array}$ & $\begin{array}{l}2 \\
1 \\
1 \\
3 \\
9\end{array}$ & $\begin{array}{r}13 \\
6 \\
6 \\
19 \\
56\end{array}$ \\
\hline
\end{tabular}

Mean duration in hospital 7.4 days (test group), and 10.4 days (control group).

Standard error of difference $=1 \cdot 32, \mathrm{P}<0.05$.

Table 8 Time of death in both groups

\begin{tabular}{|c|c|c|c|c|}
\hline \multirow[t]{2}{*}{ Time (days) } & \multicolumn{2}{|c|}{ Test group $(n=18)$} & \multicolumn{2}{|c|}{ Control group $(n=34)$} \\
\hline & $\begin{array}{l}\text { No of patients } \\
\text { who died }\end{array}$ & $\%$ & $\begin{array}{l}\text { No of patients } \\
\text { who died }\end{array}$ & $\%$ \\
\hline $\begin{array}{l}0 \text { to }<3 \\
3 \text { to }<5 \\
5 \text { to }<7 \\
7 \text { to }<9 \\
9 \text { and longer }\end{array}$ & $\begin{array}{l}4 \\
4 \\
3 \\
1 \\
6\end{array}$ & $\begin{array}{r}22 \\
22 \\
17 \\
6 \\
33\end{array}$ & $\begin{array}{r}7 \\
14 \\
7 \\
1 \\
5\end{array}$ & $\begin{array}{r}21 \\
41 \\
21 \\
3 \\
15\end{array}$ \\
\hline
\end{tabular}

discharged in a satisfactory condition, with no damage to the central nervous system.

\section{Discussion}

Tetanus antiserum with dexamethasone administered directly into the cerebrospinal fluid has reduced the mortality in tetanus neonatorum and hastened recovery from the infection (Tables 2 and 7). ATS given within 24 hours from the onset of convulsions was effective, but if given later the results were less convincing (Table 6). Sanders et al..$^{8}$ suggested that the initial spasms were due to tetanus toxin circulating free in the cerebrospinal fluid, unfixed to nervous tissues, and available for neutralisation. After 24 hours, when the toxin is presumed to be fixed to the anterior horn cells, intrathecal ATS ceases to have much effect.

Patel et al. ${ }^{11}$ studied the circulation of ATS in cerebrospinal fluid: ATS had very poor penetration into cerebrospinal fluid when not given intrathecally. Intrathecal ATS was given experimentally through two approaches, lumbar and cisternal, and was found to have almost similar effects on mortality rates in experimental animals.

In summary, we believe that the administration of intrathecal ATS with steroid is effective. Our patients in both groups had tetanus of a similar degree of severity (Table 5), they were given the same schedules of treatment, and had the same nursing care. Previous results for tetanus neonatorum $^{12}$ from the same institution gave a mortality rate of $79 \%$.

We thank Professor B B Sharma, MLN Medical College, for permitting us to carry out the study, Mr Rakesh Shukla for assistance with statistical calculations, and Dr A K Srivastava, Dr Prem Kumar, and the nursing staff of the isolation ward for their kind co-operation.

\section{References}

1 Rama Rao A. Tetanus in rural setting. Indian J Child Health 1963; 12: 700-8.

2 Shah P M, Udani P M. Analysis of the vital statistics from the rural community, Palghar. II. Perinatal, neonatal, and infant mortalities. Indian Pediatr 1969; 6: 651-68.

3 Sherrington S C. Observations with antitetanus serum in the monkey. Lancet 1917; ii: 964-6.

4 Smith J W G. Intracerebral antitoxin in experimental tetanus. Br J Exp Pathol 1966; 47: 17-24.

5 Kryzhanovsky G N, Krasnova N M. Intracisternal introduction of tetanus antitoxin in experimental tetanus intoxication (in Russian). Biull Eksp Biol Med 1971; 71 : No. 5, 38-42.

- Rossano C, Giuliagno F. Prime esperienze e risultati terapeutici con immunoglobuline umane antitetaniche per via subaracnoidea. Minerva Anestesiol 1970; 36: 725-7. 
7 Gallais H. Letter: Intérêt de l'administration intrathécale de sérum antitétanique et de corticoïdes pour le traitment du tétanos déclaré. Nouve Presse Med 1977; 6: 1571.

8 Sanders R K M, Joseph R, Martyn B, Peacock M L. Intrathecal antitetanus serum (horse) in the treatment of tetanus. Lancet 1977; i: 974-7.

9 Ildirim I. A new treatment for neonatal tetanus; antitetanic serum and prednisolone given together intrathecally. Turk J Pediatr 1967; 9: 89-95.

10 Patel J C, Joag G G. Grading of tetanus to evaluate prognosis. Indian J Med Sci 1959; 13: 834-40.

11 Patel J C, Mehta B C, Nanavati B H, Hazra A K, Rao S S, Swaminathan C S. Role of serum therapy in tetanus. Lancet $1963 ;$ i: 740-3.

12 Mehrotra S N, Srivastava A K, Agarwal V K, Mohan R. Some observations on neonatal tetanus. Pediatr Clin India 1974; 9: 151-3.

13 Pathak A T, Shah S B. Indices of severity of neonatal tetanus. Indian Pediatr 1973; 10: 87-91.

14 Vaishnava H, Neogy C N, Dixit N S, Passey A H, Gupta S, Arora N U. Clinical study of tetanus in Delhi for a period of 32 months. J Assoc Physicians India 1964; 12: 691-701.

15 Vakil B J, Iver S N, Tulpule A, Mehta A J, Tulpule T H. Observations on the aetiology and prognosis of tetanus. J Indian Med Assoc 1964; 42: 203-12.

16 Spivey O S, Grulee C G, Hickman B T. Tetanus neonatorum. J Pediatr 1953; 42: 345-51.

17 Roux E, Borrel A, Tétanos cérébral et immunité contre le tétanos. Ann Inst Pasteur 1898; 12 : 225-39.

18 Loh Siew Gek. Cited by Mazumdar H, Kaur S. Neonatal tetanus. Indian Pediatr 1971 ; 8: 145-51.

19 Lorenz K. Cited by Mazumdar H, Kaur S. Neonatal tetanus. Indian Pediatr 1971 ; 8 : 145-51.

Correspondence to $\mathrm{Dr}$ Arun Kumar Singh, 1 Professors' Residence, MLN Medical College, Allahabad, Uttar Pradesh, India.

Received 22 May 1979 